9. Лосев А. Ф. История эстетики. Памятники мировой эстетической мысли в 5 томах. Т. І. Античность, Средние века, Возрождение. Москва, 1968. 682 с.

10. Монье Ф. Опыт литературной истории Италии XV века. Кватроченто; пер. К. С. Шварсалона. СПб., 2000. 452c.

11. Хлодовский Р.И. Франческо Петрарка. Москва, 1974. 175 с.

12. Холл М. П. Энциклопедическое изложение масонской герметической, каббалистической и розенкрейцеровской символической философии: в 2-х т. Новосибирск: Наука, 1992. Т. 1. 368 с.; Т. 2. 440 с.

\title{
References
}

1. Batkin, L.N. (1970). Italian Humanists: Style of Life, Style of Thinking. Moscow [in Russian].

2. Bragina, L. M. (1977). Italian Humanism. Ethical Teachings of the 17 th -15 th centuries. Moscow [in Rus-

sian]. Russian].

3. Bragina, L.M. (1985). Compositions of the Italian Humanists of the Renaissance (XVth century). Moscow [in

4. Bragina, L. M. (1983). Social and Ethical Views of Italian Humanists. Second Half of the Fifteenth Century. Moscow: Izd. Mosk. Un-ta [in Russian].

6. Gutkovskiy, M.A. (1990). Italian Renaissance. Eds. A. M. Nemiyanov, A. S. Kantar-Gukovskaya. Leningrad: Izd. Leningradskogo Universiteta [in Russian].

7. Kondrad, N. I. (1972). West and East. Moscow [in Russian].

8. Kuznetsov, B.G. (1979). Ideas and images of the Renaissance (Science of the XIV - XVth centuries concerning the modern science). Moscow: Nauka [in Russian].

9. Losev, A.F. (1978). Aesthetics of the Renaissance. Moscow: Mysl [in Russian].

10. Losev, A.F. (1968). History of Aesthetics. Monuments of world aesthetic thought in 5 Volumes. Antiquity, Middle Ages, Renaissance. Moscow [in Russian].

11. Monje, F. (2000). Experience in the Literary History of Italy in the 15th Century. Quattrocendo. (K. S. Schwarzalon Trans). St. Petersburg [in Russian].

12. Khlodovsky, R.I. (1974). Francesco Petrarca. Moscow [in Russian].

13. Hall, M. P. (1992). An Encyclopedic Exposition of the Masonic Hermetic, Kabbalistic and Rosicrucian Symbolic Philosophy. Novosibirsk: Nauka [in Russian].

Стаття надійшла до редакції 23.08.2018 p.

UDC 001.5+378.4]:791.072.2 Moussienko

\author{
Bezruchko Oleksandr \\ Dr.sc. (Doctor of Science) in Arts, \\ Associate Professor, \\ Professor of the Department of Cinema \\ and Television Art, \\ Kyiv National University of Culture and Arts \\ ORCID 0000-0001-8360-9388 \\ oleksandr_bezruchko@ukr.net
}

\section{ANALYSIS OF SCIENCE AND CINEMA-EDUCATIONAL HERITAGE OF O.S. MOUSSIENKO (ON THE OCCASION OF THE 80TH ANNIVERSARY)}

The purpose of work is to study and analyze the scientific and cinema-educational heritage of the famous Ukrainian film critic and teacher, professor, the Honored Artist of Ukraine, a corresponding member of the National Academy of Arts of Ukraine O.S. Moussienko. Research methodology consists in application of biographical, historicalcultural, systematic and theoretically generalizing methods. The marked methodological approaches allow to collect and investigate the contribution made by Oksana Stanislavivna Moussienko into the science of cinema and media pedagogy. The scientific novelty of work lies in the fact that, unfortunately, domestic researchers not often highlight the activities of those, who devoted himself to the study of the cinema process, all its complexities, contradictions, and achievements. Conclusions. In summary, we would like to note that the set research tasks were fulfilled. The contribution made by Oksana Stanislavivna Moussienko into the science of cinema and media pedagogy was analyzed, the life path of O.S. Moussienko was studied, the circle of research interests disclosed in Moussienko's writings was considered, O.S. Moussienko's best students at the Cinema Studies Department of Screen Arts Institute of the Kyiv National I. K. KarpenkoKary Theatre, Cinema and Television University were named, and the list of her most important publications in culturological newspapers and magazines of Ukraine was provided.

Keywords: Oksana Stanislavivna Moussienko; cinema studies; cinema faculty; screen arts pedagogy; cinema studies department; professor; biographical method.

Безручко Олександр Вікторович, доктор мистецтвознавства, доцент, профресор кафедри кіно- телемистецтва Київського національного університету культури і мистецтв

Аналіз наукової і кінопедагогічної спадщини О.С. Мусієнко (до 80-річчя до дня народження)

Мета роботи. Дослідити та проаналізувати наукову і кінопедагогічну спадщину видатного українського кінознавця та педагога, професора, заслуженого діяча мистецтв України, члена-кореспондента Національної ака-

(C) Bezruchko O., 2018 
демії мистецтв України О.С. Мусієнко. Методологія дослідження полягає в застосування біографрічного, історикокультурного, систематизаційного та теоретично узагальнюючого методів. Зазначені методологічні підходи дозволяють зібрати та дослідити внесок, зроблений Оксаною Станіславівною Мусієнко в науку про кіно і в медіапедагогіку. Наукова новизна роботи зумовлена тим, що, нажаль, вітчизняні дослідники не так часто висвітлюють діяльність тих, хто присвятив себе вивченню кінопроцесу у всіх його складнощах, протиріччях і досягненнях. Висновки. Підсумовуючи вищевикладене, можна зазначити, що поставлені наукові завдання виконані: проаналізовано внесок, зроблений Оксаною Станіславівною Мусієнко в науку про кіно і в медіапедагогіку; досліджено життєвий шлях О.С. Мусієнко; розглянуто безпосереднє коло тих наукових інтересів, яким присвятила свої дослідження Мусієнко; названо найкращих учнів О.С. Мусієнко на кафедрі кінознавства Інституту екранних мистецтв Київського національного університету театру, кіно і телебачення ім. І.К. Карпенка-Карого; наведено список найголовніших іiї публікації у культурологічних газетах і журналах в Україні.

Ключові слова: Оксана Станіславівна Мусієнко; кінознавство; кінофакультет; педагогіка екранних мистецтв; кафедра кінознавства; професор; біографічний метод.

Безручко Александр Викторович, доктор искусствоведения, доцент, профрессор кино- телеискусства Киевского национального университета культуры и искусств

Анализ научного и кинопедагогического наследия О.С. Мусиенко (к 80-летию со дня рождения)

Цель работы. Исследовать и проанализировать научное и кинопедагогическое наследие выдающегося украинского киноведа и педагога, профессора, заслуженного деятеля искусств Украины, члена-корреспондента Национальной академии искусств Украины О. С. Мусиенко. Методология исследования заключается в применении биографического, историко-культурного, систематизационного и теоретически обобщающего методов. Отмеченные методологические подходы позволяют собрать и исследовать вклад, сделанный Оксаной Станиславовной Мусиенко в науку о кино и в медиапедагогику. Научная новизна работы предопределена тем, что, к сожалению, отечественные ученые не так часто исследуют деятельность тех, кто посвятил себя изучению кинопроцесса во всех его сложностях, противоречиях и достижениях. Выводы. Подытоживая вышеизложенное, можно отметить, что поставленные научные задания выполнены: проанализирован вклад, сделанный Оксаной Станиславовной Мусиенко в науку о кино и в медиапедагогику, исследован жизненный путь О.С. Мусиенко; рассмотрен непосредственный круг тех научных интересов, которым посвятила свои исследования Мусиенко; названы лучшие ученики О.С. Мусиенко на кафедре киноведения Института экранных искусств Киевского национального университета театра, кино и телевидения им. И.К. Карпенко-Карого; приведен список основных ее публикаций в культурологических газетах и журналах в Украине.

Ключевые слова: Оксана Станиславовна Мусиенко; киноведение; кинофракультет; педагогика экранных искусств; кафедра киноведения; профессор; биографический метод.

Problem statement. Ukrainian cinema studies are rich in names of the prominent history scholars, theorists of screen arts, and cinema teachers, whose contribution to the science of cinema is rich and diverse. The relevance of this research is due to the fact that, unfortunately, domestic researchers not often highlight the activities of those, who devoted themselves to the study of the cinema process, all its complexities, contradictions, and achievements.

Analysis of recent research and publications. The Ukrainian film scholars, with the exception of $\mathrm{V}$. Skurativskyi [23], I. Zubavina [3], N. Moussienko [4], and O. Bezruchko [1; 2] have not conducted an in-depth study of life, creativity and cinema teaching activity of an outstanding Ukrainian movie scholar, a leading national teacher of screen arts, PhD in Arts (1973), Professor (2005), Honored Artist of Ukraine (1998), corresponding member of the National Academy of Arts of Ukraine (2001), laureate of the USSR Filmmaker Union awards (Ukrainian National Filmmakers Union) (1978 and 1987), Oksana Stanislavivna Moussienko, who has been chairing the Cinema Studies Department of the Screen Arts Institute of the Kyiv National I.K. Karpenko-Kary Theatre, Cinema and Television University for more than twenty years and teaching there for 50 years.

The scientific tasks of this article are to analyze the contribution made by Oksana Stanislavivna Moussienko into the science of cinema and media pedagogy; to study the life path of O.S. Moussienko; to consider the circle of research interests disclosed in Moussienko's writings; to name O.S. Moussienko's best students at the Cinema Studies Department of Screen Arts Institute of the Kyiv National I. K. Karpenko-Kary Theatre, Cinema and Television University, and to give the list of her most important publications in culturological newspapers and magazines in Ukraine.

Research methodology consists in application of biographical, historical-cultural, systematic and theoretically generalizing methods. The marked methodological approaches allow to collect and investigate the contribution made by Oksana Stanislavivna Moussienko into the science of cinema and media pedagogy.

The purpose of the article. Based on the problem, the objective of this research is to investigate and analyze the science and cinema-educational heritage of the famous Ukrainian film critic and the teacher, the professor, the Honored Artist of Ukraine, the corresponding member of the National Academy of Arts of Ukraine O.S. Moussienko.

Summary. Professor Oksana Stanislavivna Moussienko is the author of numerous research papers on history and theory of cinema, which were published in scientific collections of the Kyiv National I. K. Karpenko-Kary Theatre, Cinema and Television University, National Academy of Arts and National Academy of Sciences of Ukraine, as well as in specialized periodicals of the country, namely "Novyny Kinoekranu", "Kino-Kolo", "Kino-Teatr", "Kultura I Zhyttia", and "Na Ekranakh Ukrainy". For example, for 45 years of coop- 
eration with one of the oldest Ukrainian newspaper, "Kultura I Zhyttia", Oksana Stanislavivna has published there more than fifty articles showing a wide range of her research interests, namely movie research analysis ("Kira Maratova's apocalypse" [5]; "O. Olzhych's knightly choice" [10]; "A singing squadron: notes about "Old Men Only Go to Fight»" [19]), theoretical works ("Yuriy Illenko's cinema: all the colors of the world" [9]; "Capturing the diversity of TV movie genres" [12]; "TV version. What is it like?" [20]), reviews of books on cinema ("The bearer of a deep national identity" [11]), reviews of festivals and movie retrospectives ("Two retrospectives" [7]; "Under the influence of new meetings: Kyiv held the second week of the European cinema" [13]; "Saint Petersburg brand: screen of the neighboring countries" [14]; "Polish view" [15]), movie teaching work ("«Prologue» to the future of Ukrainian cinema" [16]; "«Prologue» Festival: experience, assessments, summary" [21]; "Should one teach to watch a movie?" [22]; "Every evening after work" [25]), interviews with the leading national filmmakers ("Hrynko M.: The talent of being needed" [6]; "Peer of the century" [17]), stories about famous artists ("The secret of eternal youth" [18]) and so on.

Oksana Stanislavivna Moussienko is engaged in research in the theory and history of cinema, both domestic and foreign. Her creative works include more than 300 publications, manuals, curricula, and scripts.

According to O.S. Moussienko, she liked to present her opinion based on fresh impressions after watching. Not wanting to offend anyone, aspiring to support an artist, she, however, tried to be fair to him and herself. Moussienko $\mathrm{O}$. was amazed by gratitude expressed by the filmmakers, such as L. Bykov, M. Illenko, and V. Horpenko.

However, there were occasions, when the director felt offended, and considered her biased and subjective. Oksana Stanislavivna Moussienko admits that she was wrong several times. However, there were also the cases, when after a long time the director agreed with her opinion.

The heroine of our study saw the point in such works with local artists only, because it seemed very strange to her to review, for example, Ozone or Seidl.

Maybe like every film scholar she was and is attracted by such charismatic figures Serhiy Parajanov and Yuriy Illenko, as well as the entire brilliant Ukrainian poetic cinema film school. Although, the "city movie prose" by K. Muratova, R. Balayan, and V. Kryshtofovich remains equally interesting to her.

Unfortunately, we do not often get in sight the movie scholars, who have made an extremely important contribution to the cinema process. O.S. Moussienko is happy to have had an opportunity to write a creative portrait of I.S. Kornienko, a scientist with encyclopedic knowledge, who did so much for both creative practice and cinema pedagogy.

She recalled with great respect such powerful personalities as V.V. Tsvirkunov and S.P. Ivanov. Without them, one could barely imagine the Ukrainian poetic cinema and training of filmmakers at the cinema faculty.

Oksana Stanislavivna Moussienko also had an opportunity to work at the department with teachers, who gave very much to the students. This is, in particular, Y.S. Levin, the cooperation, with whom she described in her essay, written with sincere sympathy and gratitude, which became a part of her book. As a senior fellow, he always supported her in the early teaching activities.

O.S. Moussienko believes that we owe a lot to the movie scholars and teachers B.S. Buriak and K.H. Teplytskyi, who have invested a lot of creative energy in the training of future filmmakers [8].

O.S. Moussienko is noted in the encyclopedic manual "Foreign Media Teachers and Media Culture Theorists" [24].

O.S. Moussienko devotes much time to public work in the National Union of Cinematographers of Ukraine, where she was repeatedly elected to the governing bodies. The National Academy of Arts of Ukraine does not remain unnoticed by Oksana Stanislavivna Moussienko either, for which she was awarded the title of the corresponding member of the art theory and history department of the National Academy of Arts of Ukraine in 2001.

O.S. Moussienko always carefully watches the speeches of her students and movie scholars in press. Some of them have become serious critics, who are well versed in the cinema process and fluent in pen. Oksana Stanislavivna Moussienko first notes a wonderful journalist, Volodymyr Voitenko, who has long led "Kinokolo", a magazine, extremely popular in Ukraine, Iryna Zubavina, who combines the research and teaching work (Doctor of Arts, corresponding member of the National Academy of Sciences of Ukraine) with an active work of a contemporary film critic, and an expert in cinema education, Olena Kutsenko [8].

Two heads of departments of the Kyiv National I.K. Karpenko-Kary Theatre, Movie and Television University, namely a Doctor of Philosophical Science, Professor, Head of the Department of Social Sciences of the Kyiv National I.K. Karpenko-Kary Theatre, Movie and Television University Olena Ihorivna Onishchenko and a Doctor of Philosophical Science, Professor, Head of the Cinema Studies Department of the Screen Arts Institute of the Kyiv National I.K. Karpenko-Kary Theatre, Movie and Television University Maryna Tarasivna Braterska-Dron, wrote their diplomas under O.S. Moussienko's supervision.

The analysis of the creative way of life and an outstanding teacher today is greatly assisted by a research reference publication, "Oksana Stanislavivna Moussienko, Biographic Materials", compiled by Natalia Moussienko, a leading research fellow of the Modern Art Research Institute of the National Academy of Arts of Ukraine. The publication prepared in close cooperation with the National Parliamentary Library, namely its senior librarian Natalia Kazakova, not only provides a detailed bibliography of Professor Moussienko, and 
also contains a unique material about the family library of the Wyshynskyi-Kandyba-Moussienkos, which became one of the foundations of the teacher formation and presents the circle of Oksana Stanislavivna and her family interlocutors. The introductory article by Academician Vadym Skurativskyi not only introduces Oksana Moussienko to the reader, but also depicts the era in which she came to the cinema vividly and accurately. This research will certainly be useful to cinema historians and teachers. Also, it is interesting to a broad range of readers [4].

Many years of titanic work of Oksana Stanislavivna Moussienko in Ukrainian cinema scholarship and screen arts pedagogy is highly appreciated. She was awarded the Order of Princess Olha (2004), Gold Medal of the National Academy of Arts of Ukraine (2008), the badge for Excellence in Education of Ukraine (1997), and medals.

O.S. Moussienko is full of energy and creative ideas, continues to educate a new generation of experts on screen arts at the Cinema Studies Department of Screen Arts Institute of the Kyiv National I. K. Karpenko-Kary Theatre, Cinema and Television University. We would like to finish the article with her words full of optimism and hope, "So, there is still much to do for Ukrainian cinema scholars. We can only dream of rest!" [8].

Conclusions. In summary, we would like to note that the set research tasks were fulfilled. The contribution made by Oksana Stanislavivna Moussienko in the science of cinema and media pedagogy was analyzed, the life path of O.S. Moussienko was studied, the circle of research interests disclosed in Moussienko's writings was considered, O.S. Moussienko's best students at the Cinema Studies Department of Screen Arts Institute of the Kyiv National I. K. Karpenko-Kary Theatre, Cinema and Television University were named, and the list of her most important publications in culturological newspapers and magazines in Ukraine was provided.

However, the future research prospects remain extensive, because Oksana Stanislavivna Moussienko is full of energy and creative ideas, continues to educate a new generation of experts on screen arts at the Cinema Studies Department of Screen Arts Institute of the Kyiv National I. K. Karpenko-Kary Theatre, Cinema and Television University.

\section{תimepamypa}

1. Безручко А. Известный украинский медиапедагог О.С. Мусиенко / А. В. Безручко // Медиасфера и медиаобразование: специфика взаимодействия в современном социокультурном пространстве : сборник статей. - Могилев : Могилевский институт МВД, 2016. - Вып. 2. - С. 40-47.

2. Безручко О. Творчо-педагогічний досвід О. С. Мусієнко / О. В. Безручко // Міждисциплінарне пізнання закономірностей сучасного екранного дискурсу: зб. наукових праць / відп. ред. Г. П. Чміль, І. Б. Зубавіна. - К.: Ін-т культурології НАМ України, 2014. - С. 204-214.

3. Зубавіна І. Мистецтво любити кіно / І. Б. Зубавіна // Кіно-театр. - 2008. - № 3. - С. 46-47.

4. Мусієнко Н. Б. Мусієнко Оксана Станіславівна: матеріали до біографії / Н. Б. Мусієнко. - Київ : Логос, $2014-220 \mathrm{c}$.

5. Мусієнко О. Апокаліпсис Кіри Маратової : [про художній фільм реж. К. Муратової “Три історії”] / О. С. Мусієнко // Культура і життя. - 1997. - 9 квітня. - С. 3.

6. Мусієнко О. Гринько М. : талант бути необхідним: [бесіда з нар. арт. УРСР кіноактором М. Гриньком] / записали О. С. Мусієнко, В. Р. Слободян // Культура і життя. - 1982. - 21 лютого. - С. 5.

7. Мусієнко О. Дві ретроспективи: [Вернор Херцог і Франсуа Трюффо] / О. С. Мусієнко // Культура і життя. $-1994 .-12$ березня. - С. 3.

8. Мусієнко О. Інтерв'ю про творчу і кінопедагогічну діяльність, 18 вересня 2013 р. / О. С. Мусієнко // Приватний архів автора.

9. Мусієнко О. Кінематограф Юрія Іллєнка : всі барви світу / Оксана Мусієнко // Культура і життя. 2006. -13 вересня. - С. 2.

10. Мусієнко О. Лицарський вибір Олега Ольжича : [про документальний фільм “Олесь Ольжич: «Я камінь з Божої пращі»”. Авт. сценарію Л. Череватенко, реж. - А. Микульский ] / О. С. Мусієнко // Культура і життя. 1997. - 11 червня. - С. 4.

11. Мусієнко О. Носій глибинної національної сутності: [Рецензія на книгу Анджея Вайди "Кіно і решта світу"] / О. С. Мусієнко // Культура і життя. - 2005. - 24 червня. - С. 3.

12. Мусієнко О. Опанувати розмаїття жанрів про телевізійне кіно / О. С. Мусієнко // Культура і життя. 1977. - 24 лютого. - С. 4.

13. Мусієнко О. Під "градусом” нових зустрічей : у Києві відбувся Другий тиждень європейського кіно / О. С. Мусієнко // Культура і життя. - 1995. - 2 серпня. - С. 3.

14. Мусієнко О. Пітерська марка : екран близького зарубіжжя / О. С. Мусієнко // Культура і життя. - 1996. -29 травня. - С. 3.

15. Мусієнко О. Польський погляд / О. С. Мусієнко // Культура і життя. - 2007. - 20 червня. - С. 4.

16. Мусієнко О. "Пролог” до майбутнього українського кіно : [про фестиваль студентських фільмів] / О. С. Мусієнко // Культура і життя. - 1998. - 14 січня. - С. 3.

17. Мусієнко О. Ровесник століття: [пам'яті режисера Л. Ф. Швачка] / О. С. Мусієнко // Культура і життя. 2001. - 3 лютого. - С. 3.

18. Мусієнко О. Секрет вічної молодості: [до ювілею режисера Юрія Іллєнка] / О. С. Мусієнко // Культура і життя. $-2007 .-27$ червня. - С. 3

19. Мусієнко О. Співуча ескадрилья: нотатки про фрільм "В бій ідуть тільки старики" / О. С. Мусієнко // Культура і життя. - 1974. - 9 травня. - С. 4. 
4.

20. Мусієнко О. Телеекранізація. Яка вона? / О. С. Мусієнко // Культура і життя. - 1976. - 17 жовтня. - С.

21. Мусієнко О. Фестиваль “Пролог” : враження, оцінки, підсумки: [про фестиваль фрільмів, створених студентами кінофракультету] / О. Мусієнко, С. Кондратенко, О. Рутковський та ін. // Культура і життя. - 1990. - 11 листопада. - С. 3.

22. Мусієнко О. Чи варто вчити дивитися кіно? / О. С. Мусієнко // Сучас. пробл. худож. освіти в Україні : зб. наук. пр. / АМУ, Ін-т пробл. сучас. мистец. ; [кер. проекту А. В. Чебикін ; редкол.: В. Д. Сидоренко (голова) та ін.]. - Київ, 2008. - Вип. 4 : Медіаосвіта в Україні. Сучасний стан, проблеми розвитку. - С. 16-21.

23. Скуратовський В. Із нотаток про одну кінознавчу біографію / В. Л. Скуратівський // Мусієнко Оксана Станіславівна: матеріали до біографії / автор-упорядник Н. Мусієнко. - Київ : Логос, 2014. - С. 6-10.

24. Федоров А. Ф. Медиапедагоги и теоретики медиакультуры зарубежных стран: энциклопедический справочник / А. Ф. Федоров. - Москва : Информация для всех, 2011. - 55 с.

25. Щовечора після роботи: [обговорення фільму режисера С. Єршова студентами кінофакультету] / вела обговорення Оксана Мусієнко // Культура і життя. - 1974. - 27 червня. - С. 4.

\section{References}

1. Bezruchko, O. (2016). The Well-known Ukrainian mediateacher O.S. Moussienko. Mediasphere and mediaeducation: specific of cooperation in the modern sociocultural space: collection of scientific articles. (Issue 2), (pp. 4047). Mogilev: Mogilev Institute of MVD. [in Russian].

2. Bezruchko, O. (2014). Creatively-pedagogical experience of O.S. Moussienko. Interdisciplinary cognition of conformities to law of modern CRT discurs: collection of scientific articles. (pp. 204-214). Kyiv: Institute of Modern Arts of National Academy of Arts. [in Ukranian].

3. Zubavina, I (2008). The art to love cinema. Cinema-theatre, № 3, 47. [in Ukrainian]. [in Ukrainian].

4. Moussienko, N.B. (2014). Moussienko Oksana Stanislavivna: biographic materials. (pp. 220). Kyiv: Logos.

5. Moussienko, O.S. (1997). Kira Maratova's apocalypse. Culture and life. April, 9, (p. 3). [in Ukrainian]. Ukranian].

6. Moussienko, O.S. (1982). Hrynko M.: The talent of being needed. Culture and life. February, 21, (p. 5). [in

7. Moussienko, O.S. (1994). Two retrospectives. Culture and life. March, 12, (p. 3). [in Ukrainian].

8. Moussienko, O.S. (2013). Interview on creative and cinema teaching activities. Author's private archive. September, 18. [in Ukrainian].

9. Moussienko, O.S. (2006). Yuriy Illenko's cinema: all the colors of the world. Culture and life. September, 13, (p. 2). [in Ukrainian].

10. Moussienko, O.S. (1997). O. Olzhych's knightly choice. Culture and life. June, 11, (p. 4). [in Ukrainian]. Ukrainian].

11. Moussienko, O.S. (2005). The bearer of a deep national identity. Culture and life. June, 24, (p. 3). [in

12. Moussienko, O.S. (1977). Capturing the diversity of TV movie genres. Culture and life. February, 24, (p. 4). [in Ukrainian].

13. Moussienko, O.S. (1995). Under the influence of new meetings: Kyiv held the second week of the European cinema. Culture and life. August, 2, (p. 3). [in Ukrainian].

14. Moussienko, O.S. (1996). Saint Petersburg brand: screen of the neighboring countries. Culture and life. May, 29, (p. 3). [in Ukrainian].

15. Moussienko, O.S. (2007). Polish view. Culture and life. June, 20, (p. 4). [in Ukrainian].

[in Ukrainian].

16. Moussienko, O.S. (1998). "Prologue" to the future of Ukrainian cinema. Culture and life. January, 14, (p. 3).

17. Moussienko, O.S. (2001). Peer of the century. Culture and life. February, 3, (p. 3). [in Ukrainian].

18. Moussienko, O.S. (2007). The secret of eternal youth. Culture and life. June, 27, (p. 3). [in Ukrainian].

19. Moussienko, O.S. (1974). A singing squadron: notes about "Old Men Only Go to Fight". Culture and life. May, 9, (p. 4). [in Ukrainian].

20. Moussienko, O.S. (1976). TV version. What is it like? Culture and life. October, 17, (p. 4). [in Ukrainian].

21. Moussienko, O.S. (1990). Prologue Festival: experience, assessments, summary. Culture and life. November, 11, (p. 3). [in Ukrainian].

22. Moussienko, O.S. (2008). Should one teach to watch a movie? Modern issues of artistic education in Ukraine: collection of scientific articles. (Issue. 4), (pp. 16-21). Kyiv: Institute of Modern Arts of National Academy of Arts. [in Ukrainian].

23. Skuratovskyi V. (2014). From the notes on a movie scholar's biography: Moussienko Oksana Stanislavivna: biographic materials. (pp. 6-10). Kyiv: Logos. [in Ukrainian].

24. Fedorov, A. (2011). Foreign Media Teachers and Media Culture Theorists: Encyclopedic Handbook (pp. 55). Moscow: Information for everyone. [in Russian].

25. Moussienko, O.S. (1974). Every evening after work. Culture and life. June, 27, (p. 4). [in Ukrainian].

Стаття надійшла до редакції 27.07.2018 p. 